\title{
(息)
}

Citation:

Jones, $O$ and Kerr, MA (2012) Refreshment by the case: Use of multimedia in case study assessment. The International Journal of Management Education, 10 (3). pp. 186-200. ISSN 1472-8117 DOI: https://doi.org/10.1016/j.jjme.2012.07.002

Link to Leeds Beckett Repository record:

https://eprints.leedsbeckett.ac.uk/id/eprint/4381/

Document Version:

Article (Accepted Version)

The aim of the Leeds Beckett Repository is to provide open access to our research, as required by funder policies and permitted by publishers and copyright law.

The Leeds Beckett repository holds a wide range of publications, each of which has been checked for copyright and the relevant embargo period has been applied by the Research Services team.

We operate on a standard take-down policy. If you are the author or publisher of an output and you would like it removed from the repository, please contact us and we will investigate on a case-by-case basis.

Each thesis in the repository has been cleared where necessary by the author for third party copyright. If you would like a thesis to be removed from the repository or believe there is an issue with copyright, please contact us on openaccess@leedsbeckett.ac.uk and we will investigate on a case-by-case basis. 


\section{Refreshment by the Case: Use of Multimedia in Case Study Assessment}

Ollie Jones

Marie Kerr

Leeds Metropolitan University

Faculty of Business and Law

Rose Bowl

1 Portland gate

Leeds

LS1 3HL

01138124865

o.jones@leedsmet.ac.uk

Ollie Jones MA, MEng, PGCHE is a Teacher Fellow and Principal Lecturer at Leeds Metropolitan University, a part-time member of the University Technology Enhanced Learning [TEL] team and a TEL champion for the Faculty of Business and Law. Prior to joining Leeds Metropolitan University, Ollie was a senior manager in a large multinational business, with experience in operations, supply chain and quality management, and in recruitment of graduates. His research interests are primarily in Assessment, Learning and Teaching (ALT), particularly blended and technology enhanced learning as well as case study pedagogy.

Marie Kerr BEng MBA PGCHE is a Senior Lecturer in the Faculty of Business and Law at Leeds Metropolitan University. Her main teaching interests are Business Strategy, Operations Management and Transferable Skills Development. Prior to joining Leeds Business School in 2004, she worked for 15 years in manufacturing industry as a Mechanical Engineer and Project Manager. Her most recent industrial experience was as a Programme Manager developing component technology for a US owned automotive corporation. Her research interests include supply chain relationships and ALT matters, including Professional Development. 


\section{ABSTRACT}

This paper outlines a novel approach to developing, presenting and using a multimedia case study for the assessment of a large (circa 230 students) Operations Management module at undergraduate level on a Business Studies programme.

Engagement, realism and handling complexity are important issues in Operations Management teaching, learning and assessment. It is argued that traditional text based case studies do not address these concerns sufficiently and consequently can encourage surface learning approaches. Consultancy and simulation are more likely to be effective on these issues with the greater focus on experiential learning. However the constraints of these techniques restrict use as assessment options, particularly for large undergraduate programmes.

This paper offers tutors of Operations Management an alternative approach to facilitating experiential learning using a multimedia case. The action research reported here develops this multimedia approach, identifies the practical considerations and the potential for improved student learning outcomes. The findings indicate that this multimedia approach was engaging, realistic and challenging hence facilitated greater student interest, understanding and skills.

Keywords: Case study, pedagogy, complexity, multimedia, assessment, engagement, skill development. 


\section{INTRODUCTION: OUR CONCERNS}

Case study teaching and learning is often the most significant pedagogy in Business and Management education courses and is a long-standing and widely accepted practice (Hoskin, 1998). However this practice is not without criticism (e.g. Argyris, 1980) and there are a number of issues and limitations associated with the use of traditional text based cases particularly with increasingly large and diverse student cohorts (Brennan \& Ahmad, 2005). This research was inspired by our experience of such problems with the use of case studies, specifically in the assessment phase of a large (circa 230 students) Operations Management (OM) module at undergraduate level on a Business Studies programme.

Our four main concerns were:

1. Engagement:- The level of interest in the subject of Operations Management and students engagement with the assessment case study.

2. Skill Development:- The opportunity for the students to develop relevant employability skills

3. Realism:- The realism and complexity of the assessment case context

4. Learning Approach:- The learning approach adopted by students during their assessment

Addressing such concerns, an alternative to the text based case which has become increasingly popular over the last decade is the "live case" (Kennedy, Lawton \& Walker, 2001; Elam \& Spotts, 2004) or "field-based consulting project" 
(Heriot, Cook, Jones \& Simpson, 2008). These consultancy approaches involve students directly in working with an organisation to solve some real business problem.

However, such consultancy methods also have inherent issues and constraints. Camarero, Rodriguez \& San Jose (2010) highlight difficulties in finding and sustaining client organisations as well as tutor resource implications in managing the consultancy process. These issues can only be magnified when dealing with large student numbers.

Hence this paper outlines a novel approach to addressing these concerns through developing, presenting and using a single multimedia case study for student assessment on a large OM module at Leeds Business School. The multimedia case developed consisted of different elements of information from a local business, constructed using various media elements such as audio interviews, videos, pictures and spreadsheets. The case elements were then uploaded onto the Virtual Learning Environment (VLE). This was designed to simulate interaction with a client organisation.

Action research provided a useful and appropriate framework to focus and direct our concerns. Action research is “... a form of self-reflexive enquiry undertaken by participants in social situations in order to improve the rationality and justice of their own practices, their understanding of these practices and the situations in which these practices are carried out" (Carr \& Kemmins, 1986, p162). Taking such an approach affords the researcher-practitioner the opportunity to change a 
situation aided by reflective iterations in cycles of action and analysis. Hence this enquiry was undertaken by the module teaching team using this action-reflection process (McNiff \& Whitehead, 2006) over the course of the academic year 20082009 for the module concerned. Figure 1. Illustrates the broader approach, although the research reported here is restricted to just the initiating cycle.

\section{Figure 1: Action-Reflection Cycles of Action Research}

The majority of this paper is structured around the first elements of the action research process adapted from McNiff \& Whitehead (2006) outlined in Figure 2.

\section{Figure 2: Stages of Action Research Contextualised}

Finally we reflect on the tutor practice of designing and constructing the multimedia case and on the data gathered about the student learning and assessment experience. We conclude with some overall implications for practice and further research into this area.

To summarise, the three main objectives of this paper are:

1. Does using a multimedia case study allow progress towards alleviating our concerns on Engagement, Skill Development, Realism and Learning Approach arising from the use of text based cases for assessment?

2. What are the practical considerations of this multimedia case approach?

3. To what extent does this multimedia case approach mitigate the issues that arise when using a live case? 
Hence the next section reviews the literature to establish the wider context, structured around our four main concerns of Engagement, Skill Development, Realism and Learning Approach. 


\section{LITERATURE REVIEW: TAKING STOCK OF THE WIDER CONTEXT}

\section{Engagement}

Many authors (Kreber, 2001; Rippin, Booth, Bowie \& Jordan, 2002; Brennan \& Ahmad, 2005) have outlined the history of using case studies in business and management education over the last century. In fields such as Business and Management, it is often the primary mode of instruction (Alexander, O'Neill, Snyder \& Townsend, 1986). This growth in the use of the case study for teaching has meant that many undergraduate students are exposed to numerous text based cases each semester.

Generally, recent cases are professionally written and well researched (Wolfe, 1998). To increase engagement and interest, academics have focused on providing more stimulating and student-orientated case material with some success (O'Cinneide, 2006). However, in their study of the student experience of case use, Brennan \& Ahmad (2005) found a substantial minority (30\%) of their sample of Marketing and Management students had less than favourable attitudes towards pedagogy based on text based case studies. Our own teaching experiences in the increasingly common "massified" higher educational context concur with this finding. In fact we suggest that the current high level of use of text based case studies in such contexts can lead to "case-fatigue".

A broader problem for current Business and Management teaching is that a significant proportion of students apparently lack interest and engagement with a 
range of curriculum subjects. This is of concern not only from a student satisfaction perspective but also, as Bryson \& Hand (2007) point out, engagement of students is critical for learning outcomes to be achieved.

Interestingly Camarero, Rodriguez \& San Jose (2010) note this is evident even when students participate in a more consultancy based case approach or live case. When dealing with client businesses, such lack of engagement can damage tutor-industry relationships, sour reputations and jeopardise future student consultancy options. This highlights that whilst consulting in a live case is likely to motivate and engage through the direct contact with businesses and OM in practice, this is not always true for all students. Hence as well as the resource implications of live cases as a viable alternative to text based case studies for teaching and assessment, there are more significant risks associated with failure for both student and tutor.

Goffin (1998) and Desai \& Inman (1994) report a lack of student interest and engagement in OM in particular. Helms (1989) also found students had little interest in OM as a subject, noting that many of her students had never been inside a manufacturing operation or a service facility. She advocates factory visits as one of the potential remedies by increasing exposure, stimulating interest and increasing familiarity with terminology and processes. However this is only practical with relatively small numbers of students. This is especially true when visiting smaller firms, who form a large part of the UK economy and are a major destination for UK Business graduates (Westhead \& Matlay, 2005). 
Biggs (1996) indicates, in outlining the concept of constructive alignment, that assessment is amongst students' key concerns. Hence assessment-related activity is more likely than any other issue to attract and keep student attention. Riordan (2005, p54) underlines this, stating "what matters most may not be so much what the teacher does in front of the students but rather what the teacher asks the students to do". This shifts the focus from teacher delivery to student activity. Consequently design of assessment can be seen as a significant lever to improve engagement of students.

Using cases for assessment purposes is common practice. As Jerrard (2005, p27) suggests, "it is possible to reflect the real world of business and employment relations by designing case study-based assessment". Therefore the development of an assessment design which utilises a case study pedagogy requiring more activity and interaction from students is a perhaps a significant step towards more engagement.

\section{$\underline{\text { Skill Development }}$}

In her extensive literature review of industry relevant competencies, Jackson (2010) highlights the importance of employability skills both for graduates and the economies of those countries which were part of her study. Significantly Jackson notes the perceived gap in employability skills is highest in the UK. The gap between the required skills of practitioners and actual skills of graduates is widely acknowledged in the OM field. The literature on OM teaching points to "a lack of 
practical and professional skills development" (Morris, 1997, p42) and the persistence of this gap between "what is taught and what is relevant to practitioners in their daily jobs" (Visich \& Khumawala, 2006, p1).

Richardson (1994) notes that published text based cases, whilst being professionally presented and well structured, provide little assistance to those who are developing skills as "information gatherers". Mintzberg (1990) makes a similar argument in his discussion of Strategic Management. Jackson (2010) summarises these skills as "information management" and cites a number of sources to define this including "Comprehending information in a range of formats; assessing the quality and relevance of information to decisions and analysing, evaluating, interpreting and differentiating data" (Field, 2002 as cited by Jackson, 2010, p36).

Knight \& Yorke $(2004$, p8) attempt to define decision management competency, stating students need "the ability to handle ambiguous and complex situations". Jackson (2010) identifies that there are significant gaps in this competence from her survey of businesses employing UK graduates. We believe that as well as being a UK graduate skill gap, this skill has significant resonance for graduates working as, and with, OM practitioners. For example, Goffin (1998, p426) points to the "excitement, magnitude and complexity" of OM practice.

Rippin, Booth, Bowie \& Jordan (2002) note that one of the aims of using ambiguous and complex cases is to enable students to develop "sense-making skills" (Weick, 1995). These skills are essential in interpreting situations with 
contradictory and incomplete information, often hidden in a large quantity of case information and data. In this way, complex cases replicate a real world experience. Rippin, Booth, Bowie \& Jordan (2002) argue that Business and Management graduates need these skills for employment and that such case studies allow students to develop these skills.

However an ambiguous and complex case teaching approach often makes students uncomfortable as Rippin, Booth, Bowie \& Jordan (2002) found when discussing case study teaching with students. Students generally favoured cases with transparency, simplicity and closure. In addition, Argyris (1980) suggests that while many academics espoused the benefits of ambiguity in case study teaching, in reality they demonstrate inconsistency in behaviour often appearing to favour a pre-determined route to a solution or answer.

Despite these tendencies of students to seek and academics to provide closure, case studies clearly have the flexibility and potential to explore complexity and ambiguity. However, Rippin, Booth, Bowie \& Jordan (2002) also indicate that this potential may be reduced as cases have become more narrowly focused on short text formats with directive narrative.

In the related study of games and simulations, Ryan (2001) identifies a number of definitions of narrative. One definition which has particular relevance to Business and Management case studies states "narrative representation consists of a world (setting) situated in time, populated by individuals (characters), who 
participate in actions and happenings (events, plot) and undergo change" (Ryan, 2001, p2).

The role and value of narrative in adding interest and potentially increasing engagement with case studies has long been emphasised. For example, Booth, Bowie, Jordan \& Rippin $(2000$, p65) suggest that "good cases are characterised by verisimilitude, relevance, timeliness, and familiarity; a compelling narrative; and some kind of affective hook which will capture the students' imagination". Whilst we acknowledge this, our own experience of using the more traditional text based case in assessment is that some students appear to either mistakenly, or deliberately, utilise the narrative contained within the case study as a substitute for their own analysis.

Another issue of interest in considering narrative is that of dominant voice or perspective (Currie \& Tempest, 2008). Dominant narratives in traditional text based cases tend to be author-voice or from the "senior management" perspective. Graeme Currie and Sue Tempest suggest that multi-narrative accounts are more compatible with the increasing need to encourage students to adopt a broader stakeholder perspective in evaluating Business and Management related problems.

Ryan (2001) and Juul (2001) emphasise that narrative is an extensive part of human experience however, in games and simulations, more onus is placed on the participant to construct the narrative, than a traditional narrative setting such as the book (or indeed the text based case). 
Hence a neutral case stance, presenting multiple narratives (rather than a single privileged one), with minimal author imprint may indicate an important way forward in encouraging this participant construction already a feature of games and simulations. We contend that this more active role for the student in constructing case narrative will increase engagement and drive skill development appropriate to the multi-stakeholder environment of the OM practitioner.

In her discussion of case studies, Cameron (1999) indicates that the imprint of authors of cases can have the effect of distancing the case from reality. Given our concern on the need for greater realism, this further supports our contention above on the wide benefits of a more neutral case stance requiring some degree of student narrative construction.

\section{$\underline{\text { Realism }}$}

In his review of OM teaching, Keith Goffin highlighted the need for realism. To quote one respondent from his study, "the biggest challenge is to be in touch with reality and know what is relevant to teach" (Goffin, 1998, p445). This finding is not new with a number of authors concluding that more realism is needed to improve student perceptions of OM as a subject area (e.g. Adler, 1989).

However it is problematic to reproduce the characteristics of a working situation in educational material or in classroom learning (Helms, 1989; Nicholson, 1997). This is particularly the case in OM teaching and assessment. Goffin notes that 
several academics teaching OM across leading European Business Schools “consider it difficult to assess students' performance realistically in Operations Management, as it is such an applied subject" (Goffin, 1998, p443).

Cumming and Maxwell (1999) explore "authenticity" as a commonly applied concept for introducing more realism in education and assessment. Svinicki (2004), citing Wiggins (1998), provides six characteristics of an assessment that would qualify it as authentic. These are as follows:

1. Realistic Application: applying information or skills in a similar manner to application in the real world.

2. Judgment and Innovation: unstructured problem solving where there is no "right" answer and as such requires informed choices.

3. Realistic Action: undertaking typical real world procedures.

4. Realistic Situations: similar to the contexts in which the related skills are performed in the real world.

5. Skill Range: a wide range of skills related to complex real world problem solving.

6. Feedback: diagnostic information available to assess where and how corrections are needed.

These help define what we mean by realism or authenticity in our context. Firstly, there is a need to attempt to replicate the environment of $\mathrm{OM}$ that graduates could find themselves in. This should encompass the complexity and open ended nature of problems. Secondly, assessment should facilitate the actual utilisation of relevant concepts, situating these in an appropriate context to ensure adequate 
learning (Cumming and Maxwell, 1999). Thirdly, assessment should encourage similar procedures and diagnostic processes as would be applied by the experienced OM practitioner.

Hence our concern on the need for greater realism in case studies encompasses the need both to represent or simulate the richness and complexity of the OM practitioner's reality and to engage students in developing appropriate complexity handling skills in response to that (simulated) reality.

\section{Learning Approach}

A student's approach to learning has a significant impact on his or her level of engagement and hence, the nature of the learning outcome. Approaches are often classified as either surface or deep learning. Prosser \& Trigwell (1999) suggest that a surface approach frequently implies rote or piece-meal learning, without much understanding of purpose or context. This is contrasted with a deep approach whereby the learner seeks to understand ideas and wider meanings, driven by curiosity. The strategic learner is alert to assessment requirements and uses a blend of surface and deep approaches in an attempt to achieve the best grade possible in the time available.

Ottewill (2003) builds on this, suggesting that Business and Management students are probably extrinsically rather than intrinsically motivated. Hence a focus on achieving high grades and enhancing job prospects is more likely than a desire to explore and understand the subject area itself. Arguably this is even 
more relevant in the current economic conditions in the UK, with rising graduate unemployment. He proposes that this instrumentality of learners is shown through symptoms such as a low boredom threshold, high dependency on tutors, a reluctance to search out learning resources and an "unhealthy preoccupation with summative assessment”, (Ottewill, 2003, p190). He acknowledges though that, while there are likely to be many students who are towards the instrumental end of the spectrum, actually student learning approaches and motivations form a much more complex blend than such a linear idea might imply.

Furthermore, he notes that teaching strategies can influence learning approaches adopted by students. His concern is focused on the implications for teaching strategies, in order to avoid the inadvertent reinforcement of instrumentality in the learner by the teacher through "failing to provide the stimulus for students to become more expressive in their learning" (Ottewill, 2003, p193). He suggests that creativity in teaching and learning is required. Communication to students about other possible motivations for, and benefits from, studying the subject is also important.

Ottewill does briefly mention the need for varied assessment but does not emphasise the connection that Biggs (1996) does, in his constructive alignment methodology, that assessment drives learning in a fundamental way. It is interesting to consider this lack of emphasis in the light of the "unhealthy preoccupation" mentioned earlier. We argue here for constructive alignment as a robust tool whatever the student's initial mind set or motivation. 
Therefore teachers in Higher Education should, as Biggs indicates, utilise assessment as a powerful lever to encourage deep learning by appropriate assessment (and subsequently module and course) design.

Lundberg, Rainsford, Shay and Young provide a taxonomy of nine different case designs. Most pertinent to this study is the "Application Case". This is defined as a case which "describes the application of a management technique or describes a situation in which the student can apply some known technique" (Lundberg, Rainsford, Shay \& Young, 2001, p460).

Kreber highlights the ultimate task of a case learning approach "is to use one's theoretical knowledge in the field and apply it to the real life situation" (Kreber, 2001, p222). Rippin, Booth, Bowie \& Jordan (2002) suggest where the case study teaching mode is "case as development concept", the case is the experience rather than a proxy for experience. Kreber (2001) takes this idea further using the conceptual framework of Kolb (1984), proposing that students learn through the "experiential" approaches of using the case study, using all four phases of Kolb's learning cycle. This could imply that the more "real" the experience, the greater the potential for learning. Camarero, Rodriguez \& San Jose (2010) summarise that the learning activities that are more experiential increase student learning, motivation, integration of theory and practice and skill development. 
Gurd (2001) and Brennan \& Ahmad (2005) argue that to capitalise on the experiential potential of the case is difficult and costly, making the approach less suitable for large undergraduate courses. Interestingly, Gurd notes earlier in his paper that "the shift to on-line education raises new issues for the way cases are taught”, (Gurd, 2001:p1) but does not expand on the potential of such technology to alleviate the resource concerns he later highlights. We explore in this research the potential role of the VLE in facilitating experiential learning through assessment engagement.

Gurd goes on to state "a major issue remains relating to the teaching of cases using new technologies" (Gurd, 2001, p6). He also calls for further academic research on how well the case approach works as a learning device. He suggests that while cases are presumed to be beneficial, academics tend not to examine issues such as "which cases produce the best outcomes".

In this study, we are attempting to respond to both of Gurd's challenges whilst extending our particular focus on assessment. In line with Brown (2004) in her call for "Assessment for Learning", we see this as providing the main opportunity to engage students with the subject and to generate learning. 


\section{LEEDS METROPOLITAN UNIVERSITY - FACULTY OF BUSINESS \& LAW CONTEXT: DRIVERS AND CONSTRAINTS}

The module concerned - Operations Management is a level 5 core module taken by 230 business and management students in a single semester delivery. Previously the module had been assessed by asking students to complete an analysis of a text based case study. Students were asked to apply theory from the module in order to identify and solve operational problems and to relate these to the overall performance of the business.

A number of the submissions were descriptive and contained prose taken verbatim from the case study text. Many students therefore did not apply their theoretical knowledge gained from lectures to "the real life situation" as advocated by Kreber (2001) as the ultimate task of a case learning approach.

This possibly indicates a significant number of students taking a surface learning approach. It seems students lacked sufficient understanding of the relevant theory to transfer that knowledge to the case situation. As such the previous assessment design failed to stimulate deep learning approaches in these students. We contend that it did not provide enough of a "concrete experience" (Kolb, 1984) to develop experiential learning through the case study as suggested by Rippin, Booth, Bowie \& Jordan (2002) and Kreber (2001). Module evaluations indicated that students thought the cases "dull" or "boring" and as such the case study for the assessment did not engage the students in sufficient numbers. 
At Leeds Metropolitan University (LMU), a typical business undergraduate studying six subject specific modules in their first year could have been exposed to over seventy cases of various lengths by the time they reach the start of second year. Therefore "case fatigue" leading to disengagement was a concern to the module team as discussed earlier.

Teaching OM using simulations is a common and often successful approach (Smith, 1990; Goffin, 1998; Sun, 1998), and can assist in alleviating the issues of engagement, realism, skill development and learning approaches of concern here. However, whilst the students are studying the OM module, they are simultaneously participating in a strategic business simulation in another module. Hence course design issues constrained the choices of the module team in moving forward to address our concerns.

\section{Live Cases: a dead end!}

A number of authors (Kennedy, Lawton \& Walker, 2001; Elam \& Spotts, 2004; Heriot, Cook, Jones \& Simpson, 2008; Camarero, Rodriguez \& San Jose, 2010) have investigated the use of live cases. Typically these often consist of student groups working as consultants to real clients on a business problem that relates to a field or fields of their studies. The main examples, cited above, appear to be mainly from Marketing education, but there is also one in the OM subject (Heriot, Cook, Jones \& Simpson, 2008). 
One significant problem for using this approach is that some subjects are predominately externally focused, for example Marketing. This allows students to research, investigate and solve the problem with less client contact and access than a subject like OM which is predominately internally focused.

All the authors noted above report significant successes for student learning and engagement. However Camarero, Rodriguez \& San Jose (2010) highlight some issues with the use of live cases:

- Motivation - Concerns that students may be initially unmotivated, requiring additional incentives to engage with the client consultancy process

- Too much realism - Concerns that the validity of the information and the level of complexity may not be appropriate or helpful.

- Definition of the assignment - Concerns about the suitability of the client's problem.

- Company participation - Difficulties in "recruiting" companies and sustaining their participation during the consultancy scheme

- Time devoted by tutors - Concerns about demands on tutor time in managing and controlling students and their interactions with the client The above is in addition to the inherent risks and consequences of poor performance for students, tutors and organisations involved as highlighted in our discussion in the Literature Review.

A further course-level constraint influencing our research direction is that the students studying the OM module will in the next and final level of their undergraduate studies undertake a live consultancy project, almost identical to 
those discussed in the literature, but focused more on the application of Strategic Management.

Hence using either simulations or live consultancy projects were not viable options open to the module team, and therefore channelled investigation into other case assessment design options. For any alternatives to be sustainable it must be able to mitigate some of the issues with live cases raised by Camarero, Rodriguez \& San Jose (2010) whilst delivering benefits such as more opportunity for experiential, deep learning and student engagement.

\section{$\underline{\text { Summary }}$}

As discussed previously case studies are intended to provide a more realistic learning opportunity but often fail to deliver this. This affects the development of desirable employability skills such as handling complexity, the promotion of deeper, applied learning and the engagement of students. Whilst live cases have been successfully used to alleviate some of these issues, they are not always viable or appropriate, and bring issues of their own. Hence there is sufficient justification for investigating a multimedia case approach in the field of $\mathrm{OM}$ assessment. 


\section{MULTI MEDIA CASE PILOT: A WAY FORWARD}

Helms (1989) suggests that OM students visit businesses in order to improve their engagement, while Heriot, Cook, Jones \& Simpson (2008) emphasise the virtues of live cases for the same reason and to improve student learning. The multimedia case was designed to combine both approaches by simulating the experience of a first "site visit" for a graduate working on an operations improvement project. We enlisted the support of the owner of a local small business $\left(20^{\text {th }}\right.$ Century Fires $\left.{ }^{1}\right)$ in allowing the module team access to film the key processes, interview employees, and gather relevant data and documentation. The company was encouraged to participate by the offer of consultancy from both the participating tutors and a selection of high scoring students from the assessment task.

Based on practitioner experience within the module team, and with reference to curriculum of the module, a Case Environmental Map was developed by contemplating what types of media and information an OM graduate might typically be exposed to. This is outlined in Figure 3 .

\section{Figure 3: Multimedia Environmental Map}

\footnotetext{
${ }^{1}$ We would like to thank Mr Tim Swindlehirst, Managing Director of c20 Fires for his kind assistance.
} 
Following this, an initial "case protocol" (Yin, 1994) was constructed to facilitate the efficient and effective collecting of data from $20^{\text {th }}$ Century Fires. This considered tutor time at the site, ensuring elements were not missed, the time and resource required of the client business and in particular the need to avoid return visits. The protocol was based on both the Case Environmental Map and on ensuring that relevant data was available to answer potential assessment questions. We visited $20^{\text {th }}$ Century Fires (a manufacturing business with approximately 10 employees) over 2 non-consecutive days and constructed the case using the elements shown in Table 1 below.

\section{Table 1: Case data collected and compiled}

The collected data first had to be edited, and reviewed for clarity and suitability. Time was allowed for $20^{\text {th }}$ Century Fires to review the material before it was released to the students. The case elements were then uploaded to Leeds Metropolitan University's VLE. The material was presented in a non-linear fashion so as to ensure students did not follow a pre-determined narrative and included perspectives from different roles. The case material was released to students in the VLE after 5 weeks of teaching, 11 weeks prior to the assessment deadline.

To assist the students develop the sense-making skills (Weick, 1995) and to help them handle the complexity (Knight \& Yorke, 2004), an additional question was added to the assessment task which was to "process map" the operation. This also provided the opportunity for students to learn and demonstrate more applied 
aspects of the subject as requested by Goffin (1998). The marking criteria for this assessment was altered from previous years and explicit credit given for this "process mapping" in recognition of the importance of this "sense-making" complexity-handling skill and the substantial student effort involved. 


\section{METHODS: EVALUATION OF PROGRESS}

The trial development of a multimedia case study for assessment was undertaken with a view to initiating an action-reflection process, (McNiff \& Whitehead, 2006) focusing on the following research questions:

1. Does using a multimedia case study allow progress towards alleviating our concerns on Engagement, Skill Development, Realism and Learning Approach arising from the use of text based cases for assessment?

2. What are the practical considerations of this multimedia case approach?

3. To what extent does this multimedia case approach mitigate the issues that arise when using a live case?

In the traditions of action research, we are not seeking to establish a cause and effect relationship, but to see if the potential exists to influence outcomes. McNiff \& Whitehead (2006, p9) define Action Research to be a "disciplined systematic process" as follows:

1. "Take stock of what is going on

2. Identify a concern

3. Think of a possible way forward

4. Try it out

5. Monitor the action by gathering data to show what is happening 

6. Evaluate progress by establishing procedures for making judgements about what is happening
7. Test the validity of accounts of learning
8. Modify practice in the light of the evaluation"

This paper outlines the steps 1 to 6 from the above list.

The evaluation methods available to us are not sufficient to be able to make claims of validity on all the concerns. In particular this was only the second time this module had run as a full 15 credit module and, as mentioned previously, the assessment questions had been changed for this cohort. Hence there was little comparative data, or an appropriate basis for comparison in terms of student performance, especially the learning approach. We believe that in order to develop the validity of these ideas, more collaborative research is needed to compare the multimedia case approach to text based case study assessment within the same subject. This also would include some more robust evaluative techniques such as thematic analysis, Learning Objectives Questionnaires (Norton, 2009) and some review of statistical significance in the comparative data.

Data was gathered from a number of sources using a combination of qualitative and quantitative sources as espoused by Norton (2009). This consisted of 1 indepth student interview, 1 focus group of 5 students, 49 module evaluation questionnaires (primarily quantitative with fields for qualitative comment) from 188 who submitted the assignments, and the VLE-usage statistics. 
The module evaluation survey used followed a standard University-wide template and hence did not ask specific questions about the multimedia case assessment. Hence the results from this survey on the multimedia nature of the assessment were instigated by student comments which we collated into the three issues of realism, complexity and suitability as show later in our Findings.

The interviews and focus group used semi-structured questions to establish responses to the initial concerns, but also to understand the students' personal perspectives, and their learning approaches to the assessment task. The key questions for the interview and focus group were as follows:

- Did the case seem more interesting than a traditional written case? This question was intended to explore engagement and learning approach as connected concerns.

- Did the case appear complex? This question was intended to explore the concern of skill development with complexity-handling skills as a central issue.

- Did the case reflect reality more closely than a traditional written case? This question was intended to explore the concern of realism.

It was also hoped that the unstructured part of the process would yield some comments from students about their learning approach and any information management skills they might feel they have developed. 
The qualitative comments from the interview and focus group were compiled together with the filtered / collated comments about the multimedia case assessment from the module evaluation survey. These were then deconstructed into "information units" (Norton, 2009). These units were then mapped where possible to the four concerns looking for potential influence.

The VLE system itself was a useful source of data however only allowed some degree of interrogation as to what files within the case the students as a group accessed and how often. Hence we were able to collect some overall usage statistics but were not able, for example, to connect individual usage profiles with assessment grades achieved.

Finally the module team used a series of meetings after the assessment had been completed in order to reflect and produce some observations of the experience of setting and marking the multimedia case study. In particular we wanted to compare the issues that arise when using live cases as indicated by Camarero, Rodriguez \& San Jose (2010) and to see if the multimedia case approach addressed or mitigated them.

Apart from not completing the action research cycle at this time, the other limitations of this evaluation phase are that the students were not asked in the quantitative survey whether they found the multimedia case more interesting and engaging than a text based case. In retrospect, a specifically designed module evaluation survey was needed rather than using the University-wide template. There are difficulties in generalisibility of action research to other contexts, and 
this is further constrained here by not completing the action cycle at this time. However we believe that this pilot study shows enough promise to warrant a more substantial action research approach. 


\section{FINDINGS}

\section{$\underline{\text { VLE-Usage Statistics }}$}

Gibbs \& Simpson (2004) propose a number of conditions under which assessment supports learning. Condition 1 on their list concerns the importance of "time on task" to student learning. Empirical evidence supports a significant positive relationship between student time spent undertaking a learning task and their eventual levels of achievement. Clearly the relationship between effort-in and quality-out is more complex than this and not all time spent on an assessment task will be productive in terms of learning (Kember, $\mathrm{Ng}$, Tse, Wong \& Pomfret, 1996). However the use of the VLE here means that we could at least track basic levels of activity as students accessed the case material. The VLEusage statistics show a high level of basic engagement or activity in accessing the case material, with an average of 8 hits per student for the most popular element (or file). Table 2 below shows the most popular "hits" in terms of case elements.

\section{Table 2: Most Popular Hits from the VLE Case Site}

Whilst this is not surprising as VLE-hosted material was required viewing for student assessment (no hard copy material was made available), it does show that students spent significant amount of time engaging with the assessment task. The "Other" section in Table 2 was over 10,000 hits because this contained the 
individual case media elements, including case pictures and more detailed focused data (see Figure 4 below).

Figure 4: Hits from the "Other" Section

Figure 4 shows that based on a cohort size of 188 students, the ten most popular case elements were accessed at least once. It is interesting to note that students appeared to be selective in which media elements of the case to access, possibly indicating some prioritising of the case complexity.

Module Evaluation Survey Data

The quantitative survey data shown in Figures $5 \mathrm{a}, 5 \mathrm{~b}$ and $5 \mathrm{c}$ below provide some evidence that the students found the multimedia case approach realistic, complex and suitable.

Figure 5a: Case Realism Quantitative Survey Data

Figure 5b: Case Complexity Quantitative Survey Data

Figure 5c: Suitability Survey Data 
Focus Group and Interview Data

Table 3: Qualitative Comment Mapping

\section{Engagement}

From Table 3 above summarising key aspects of the qualitative data, it can be seen that some students appeared to find the case interesting. One student expressed the view that despite the business sector not being of natural interest to her, she still found the case engaging.

\section{Skill Development}

The qualitative comments supports the quantitative data about the perceived complexity, enhanced by some (limited) evidence that the complexity was bounded enough not to the make the assessment task too difficult. This is supported by the fact that no more students failed the assessment than is usual across the level, or in a basic comparison to the previous year on this OM module (2\%). The case approach appeared to allow some students to develop the ability to make connections and handle the complexity. There were a number of comments in the module survey about the assessment being "hard" or "difficult", but only one student wanted to return to a text case. A number of students suggested reducing the case complexity slightly and being allowed more time for the assessment. Although not asked directly about information management skills, students had noticed these were necessary and attached some value to the development of these in relation to employability skill (Jackson, 2010). 


\section{Realism}

Again the qualitative data supports the quantitative comments about the realism of the approach, and one student (unprompted) compares traditional narrative cases unfavourably with the multi-media case approach.

\section{Learning Approach}

The comments in the last row of Table 3 offer perhaps a glimpse of different learning approaches taken by students, but as commented earlier, more research is required in this area.

\section{Learning Outcomes}

As stated previously, because of the lack of truly comparative data, it was not appropriate to analyse the assessment outcomes by using grade statistics. Hence in order to explore this further, we attempted to map student performance against Entwistle's map of levels of conceptual learning which show progression from "reproducing" to "transformation", (Entwistle, 2000). Table 4 below shows this mapping.

\section{Table 4: Mapping Learning Outcomes to Conceptions of Learning}

The new part of the assignment which asked students to "process map" was successful in moving almost all students to at least level (3) Relating as shown in Table 4. That is, they had to apply the relevant knowledge and skills in order to complete and pass that element of the assessment. In the previous assessment only a handful of students would have attempted that level of task. Whilst the 
"process map" task could have been set on a text-based case, this would have likely been at too simplistic a level and not been authentic to OM practice, where this procedure is a basic conceptual and practical unit of analysis.

Given the research design limitations of this study, it is difficult to ascertain whether high levels of learning in the remaining part of the assessment were achieved. However we did find a significant reduction in level (2) Describing (as shown in Table 4) in that regurgitation of text from the case was less prevalent, from at least $25 \%$ of papers in the previous year to almost none in this cohort. It also seems that the introduction of a different type of case study requiring personal investigation reduced the number of students repeating theoretical material from text books, although this was less marked. This was perhaps due to the case study appearing to be a larger constituent of the overall assessment and learning tasks.

Possibly related to more students finding the case stimulating, we saw a significant rise in creativity in both recommendations and comments, although unfortunately these were not often underpinned by analysis. This does appear to show an increase in level (3) Relating as shown in Table 4 and is in a more transformative direction, towards deep learning rather than simple repetition. We also noted more instances of students using evidence that they had found within the case material to justify a particular statement. This idea of "finding" suitable evidence correlates with the student who commented that "it was quite hard to get the good stuff out of it to use, because there was quite a lot of stuff that wasn't relevant". 
It was possible to map some of the student comments onto levels (4) Explaining and (5) Conceiving of this framework, as shown in Table 5 below, to highlight instances where deeper learning may have occurred as a result of using this approach.

Table 5: Mapping Learning Outcomes to Student Comments 


\section{PRACTICE OBSERVATIONS AND REFLECTIONS}

We will now discuss the practical considerations of this multimedia case approach for tutors and students. In an attempt to demonstrate whether this approach mitigates the issues that arise when using live cases as indicated by Camarero, Rodriguez \& San Jose (2010), these live case concerns will be used here to structure our own practice observations and reflections.

- Motivation - Concerns that students may be initially unmotivated, requiring additional incentives to engage with the client consultancy process

The multimedia case was made available early in the assessment cycle, but students were free not to engage with the virtual client case until they decided to begin their assessment task. This was useful in that students who started later did not disadvantage themselves as the client interface element of the live case had already been completed and deposited on the VLE. However due to the amount of work required in absorbing the various media elements, some students commented in the focus group that they should not have started just a few days before the assessment deadline. This was despite repeated guidance from the module tutors.

- Too much realism - Concerns that the validity of the information and the level of complexity may not be appropriate or helpful. 
The advantage of the multimedia case over a client consultancy project is that the tutor can define and control the limits of the contextual complexity. Indeed it transpired that deciding what data to include or exclude, and what information to simplify was an important task. For example the case business, $20^{\text {th }}$ Century Fires, had two main income and activity streams. The module team decided to focus the multimedia assessment case on just one of these income streams. Hence the other business income stream was de-emphasised in presented material.

It was found to be useful to have one media element, such as meeting minutes, where fabricated or simulated data could be deposited. This afforded the opportunity to include implicit information and knowledge gained by the tutor when visiting the business, or to avoid too many discrete media elements. It was essential therefore that the case protocol was allowed to develop and change during our two client visits, especially where significant areas of interest in relation to the subject became apparent in the business.

Students' views were mixed on the change in complexity from short and largely text based teaching cases in tutorial classes to a large assessment multimedia case, with some finding this an issue and others not.

\section{- Definition of the assignment - Concerns about the suitability of the} client's problem. 
The multimedia case allowed tutors to focus on areas of the business's operation that had resonances with the learning outcomes of the module. It provided opportunity for students to practice skills, apply techniques, and had appropriate problems for the level of study.

- Company participation - Difficulties in "recruiting" companies and sustaining their participation during the consultancy scheme

One of the significant benefits of the multimedia case approach is that only one client company is required to produce the assessment vehicle and this company is selected by the tutor, rather than by multiple groups of students. This is more pertinent if the assessment model is to be sustainable as it avoids the same businesses being contacted year after year by students. Participation of the client company is restricted to a preliminary discussion and one or two site visits, rather than a protracted relationship requiring time and resource commitments from the client. This was initially a concern to a number of companies with whom preliminary discussions were held.

- Time devoted by tutors - Concerns about demands on tutor time in managing and controlling students and their interactions with the client

The multimedia case means that it is more feasible for students to undertake an individual assessment on a live case, as finding individual live cases for a large cohort would be difficult. This therefore reduces the group management role of the tutor and, as mentioned before, the interactions with any external client is 
much less. Furthermore clients only interact with academic staff, rather than students, hence reducing potential issues and risks for all parties.

However a key issue emerging from our experiences of case construction was staff workload. Tasks including multiple site visits and editing the data, especially voice and video data, were resource intensive, even with the construction of case protocol prior to data collection. This was due both to the volume of collected data, and the software editing skills that needed to be learnt by tutors. This was mitigated slightly by dispersing and sharing the workload amongst the module team. The client organisation found the case protocol very useful in helping them manage the access and resources efficiently for the site visits and data collection.

There were technical problems for students accessing some of the case material on the VLE, all related to the institutional VLE infrastructure and internet browser settings on student computers, both within the University and externally. In addition some students complained about the quality and clarity of voice recordings and the length of the interview pod-casts. From informal conversations, students also appeared to value the immediacy of the case, in terms of visibility and access to a range of information and case employees. Students also suggested that knowing their work could be used to form the basis of a consultancy report for the case business gave the work more meaning and improved their motivation. This benefit is therefore a simulated outcome of live case consultancy. 


\section{CONCLUSIONS}

We conclude by summarising our finding and observations in the practice of designing, constructing and marking the multimedia case assessment in comparison to using live cases.

The three main objectives of paper were;

1. Does using a multimedia case study allow progress towards alleviating our concerns on Engagement, Skill Development, Realism and Learning Approach arising from the use of text based cases for assessment?

2. What are the practical considerations of this multimedia case approach?

3. To what extent does this multimedia case approach mitigate the issues that arise when using a live case?

The literature supports the view that engagement, realism, and handling complexity are important in $\mathrm{OM}$, and that traditional text based case studies often do not provide enough experiential learning to address these concerns. The research data collected as part of the action research cycle indicated that some students found the case more stimulating and engaging. Most students found the case more realistic. Some valued the challenge to develop their skills and contribute to a consultancy report for the case business. Most students appeared to view the case as complex, and challenging but on balance were supportive of the multimedia case approach. 
The action reflection stages completed offer indications that this approach could address these concerns but more research is required in this area to validate these claims, especially whether it leads to different learning approaches taken by students and improved assessment (hence learning) outcomes.

The live case approach is a proven technique for improving engagement and experiential learning but has constraints and is not always an assessment option available to tutors. The multimedia case can offer an alternative by combining the two approaches of a "site visit" and a live business problem. This multimedia approach can also offset some of the issues that arise when using live cases.

For VLE-hosted multimedia cases used in teaching or assessment, the VLE interrogation process could be used for more detailed evaluation of learning, as this kind of data is not available for text based cases.

Overall, this single case study has provided evidence of the benefits of using VLE-hosted multimedia case studies in Operations Management. It clearly opens up options for innovative teaching and assessment with large cohorts of inexperienced undergraduates, perhaps in other areas of Business and Management studies and possibly other unrelated subjects. We hope that our initial research reported here will encourage further research in these areas. 


\section{REFERENCES}

Adler, P. S. (1989). When knowledge is the critical resource, knowledge management is the critical task, IEEE Transactions on Engineering Management, 36(2), 87-94

Alexander, L.D., O’Neill, H.M., Snyder, N.H. \& Townsend, J.B. (1986). How academy members teach the business policy/strategic management course, Journal of Management Case Studies, 2(4), 334-344.

Argyris, C. (1980). Some Limitations of the Case Method: Experiences in a Management Development Program, Academy of Management Review, 5(2), 291-298.

Biggs, J. B. (1996). Enhancing teaching through constructive alignment, Higher Education, 32, 347-364.

Booth, C., Bowie, S., Jordan, J. \& Rippin, A. (2000). The Use of the Case Method in Large and Diverse Undergraduate Business Programmes: Problems and Issues, International Journal of Management Education, 1(1), 62-75.

Brennan, R. \& Ahmad, S. J. (2005). Using case studies in management education: the student perspective, International Journal of Management Education, 4(3), 21-30.

Brown, S. (2004). Assessment for Learning, Learning and Teaching in Higher Education, 1, 81-89

Bryson, C. \& Hand, L. (2007). The Role of Engagement in Inspiring Teaching and Learning, Innovations in Education and Teaching International, 44(4), 349-362. 
Camarero, C., Rodriguez, J. \& San Jose, R. (2010). A comparison of the learning effectiveness of live cases and classroom projects, International Journal of Management Education, 8(3), 83-94.

Cameron, S. (1999). The Business Student's Handbook: Developing transferable skills, FT Pitman Publishing, London.

Carr, M. \& Kemmins, S. (1986). Becoming critical: Knowing through action research, Deakin University Press, Geelong, Victoria.

Cumming, J. J. \& Maxwell, G. S. (1999). Contextualising Authentic Assessment, Assessment in Education, 6(2), 177-194.

Currie, G. \& Tempest, S. (2008). Moving towards reflexive use of teaching cases within the MBA, International Journal of Management Education, 7(1), 41-50.

Desai, K. \& Inman, R. A. (1994). Student Bias against POM Coursework and Manufacturing, International Journal of Operations \& Production Management, 14(8), 70-87.

Elam, E. L. R. \& Spotts, H. E. (2004). Achieving Marketing Curriculum Integration: A Live Case Study Approach, Journal of Marketing Education, 26, 50-65.

Entwistle, N. (2000). Promoting deep learning through teaching and assessment: conceptual frameworks and educational contexts, Paper presented at the TLRP Conference, Leicester, November

Field, L. (2002). Industry speaks! Skill requirements of leading Australian workplaces, DEST, Canberra, Australia.

Gibbs, G. \& Simpson, C. (2004). Conditions Under Which Assessment Supports Students' Learning, Learning and Teaching in Higher Education, 1, 3-30. 
Goffin, K. (1998). Operations management teaching on European MBA programmes, International Journal of Operations \& Production Management, 18(5), 424-451.

Gurd, B. (2001). The Importance and Role of Management Case Studies, The Management Case Study Journal, 1(1), 1-8.

Helms, M. M. (1989) To Produce Interest in Production, Just Open the Factory Door, Production \& Inventory Management Journal, 30(2), 72-74.

Heriot, K. C., Cook, R., Jones, R. C. \& Simpson, L. (2008). The Use of Student Consulting Projects as an Active Learning Pedagogy: A Case Study in a Production/Operations Management Course, Decision Sciences Journal of Innovative Education, 6(2), 463-481.

Hoskin, K. (1998). The mysterious case of the case study: a re-thinking, Accounting Education, 7, 57-70.

Jackson, D. (2010). An international profile of industry-relevant competencies and skill gaps in modern graduates, International Journal of Management Education, 8(3), 29-58.

Jerrard, M. A. (2005). Assessing Student Learning and Skills Using the Case Study Method, Journal of New Business Ideas and Trends, 3(1), 27-36.

Juul, J. (2001). Games Telling stories?- A brief note on games and narratives, Game Studies, 1(1), 1-12.

Kember, D., Ng, S., Tse, H., Wong, E. T. T. \& Pomfret, M. (2001). An examination of the interrelationships between workload, study time, learning approaches and academic outcomes, Studies in Higher Education, 21(3), 347-358. 
Kennedy, E. J., Lawton, L. \& Walker, E. (2001). The Case for Using Live Cases:

Shifting the Paradigm in Marketing Education, Journal of Marketing Education, 23, 145-151.

Knight, P. \& Yorke, M. (2004). Learning, curriculum and employability in higher education, Routledge Falmer, London.

Kolb, D. A. (1984). Experiential Learning: Experience as the source of learning and development, Prentice-Hall, New Jersey.

Kreber, C. (2001). Learning Experientially through Case Studies? A Conceptual Analysis, Teaching in Higher Education, 6(2), 217-228.

Lundberg, C. C., Rainsford, P., Shay, J. P. \& Young, C. A. (2001). Case Writing Reconsidered, Journal of Management Education, 25(4), 450-463.

McNiff, J. \& Whitehead, J. (2006). All You Need To Know About Action Research, Sage Publications Ltd, London.

Mintzberg, H. (1990). The Design School: Reconsidering the Basic Premises of Strategic Management, Strategic Management Journal, 11(3), 171-195.

Morris, J. S. (1997). Teaching production and operations management, Production and Inventory Management Journal, 38(2), 42-47.

Nicholson, A. (1997). Bringing management reality into the classroom - the development of interactive learning, Journal of Management Development, 16(6), 438-451.

Norton, L. S. (2009) Action Research in Teaching and Learning: A practical guide to conducting pedagogical research in universities, Routledge, London. 
O'Cinneide, B. (2006). Developing and testing student oriented case studies: The production process and classroom/examination experiences with 'entertaining' topics, Journal of European Industrial Training, 30(5), 349-364.

Ottewill, R. M. (2003). What's wrong with instrumental learning? The case of business and management, Education + Training, 45(4), 189-196.

Prosser, M. \& Trigwell, K. (1999). Understanding Learning and Teaching: The Experience in Higher Education, Open University Press, Buckingham

Richardson, B. (1994). Towards a Comprehensive View of the Case Method in Management Development, Industrial and Commercial Training, 26(9), 3-10.

Riordan, T. (2005). Education for the 21st Century: Teaching, Learning, and Assessment, Change, 37(1), 52-56.

Rippin, A., Booth, C., Bowie, S. \& Jordan, J. (2002). A Complex Case: using the case study method to explore uncertainty and ambiguity in undergraduate business education, Teaching in Higher Education, 7(4), 429-441.

Ryan, M. (2001). Beyond Myth and Metaphor - The Case of Narrative in Digital Media, Game Studies, 1(1), 1-14.

Smith, D.J. (1990). The Use of Microcomputer-based Simulation Models in the Teaching of Operations Management, International Journal of Operations \& Production Management, 10(5), 5-16.

Sun, H. (1998). A game for the education and training of production/operations management, Education + Training, 40(9), 411-416.

Svinicki, M. D. (2004). Authentic Assessment: Testing in Reality, New Directions for Teaching and Learning, 100(Winter), 23-29. 
Visich, J. K. \& Khumawala, B. M. (2006). Operations Management Curricula: Literature Review and Analysis, Journal of Statistics and Management Systems, 9(3), 661-687.

Weick, K. E.(1995). Sensemaking in Organisations, Sage Publications Inc, Thousand Oaks, California.

Wenger, E., McDermott, R. \& Snyder, W. (2002) Cultivating communities of practice: a guide to managing knowledge, Harvard Business School Press, Westhead, P. \& Matlay, H. (2005) Graduate Employment in SMEs: a longitudinal perspective, Journal of Small Business and Enterprise Development, 12(3), 353365.

Wiggins, G. (1998). Educative Assessment: Designing Assessments to Inform and Improve Student Performance, Jossey-Bass, San Francisco.

Wolfe, J. (1998). New developments in the use of cases for learning, Journal of Workplace Learning, 10(6/7), 320-323.

Yin, R. K. (1994). Case Study Research; Design and Methods, Sage Publications Inc, Thousand Oaks, California. 
Figure 1: Action-Reflection Cycles of Action Research

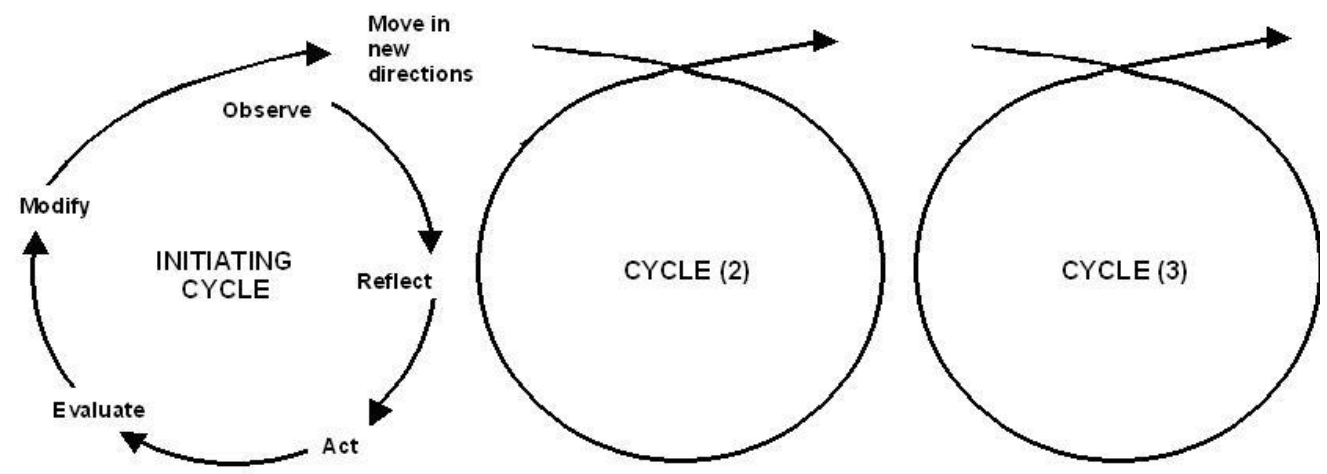

Figure 2: Stages of Action Research Contextualised

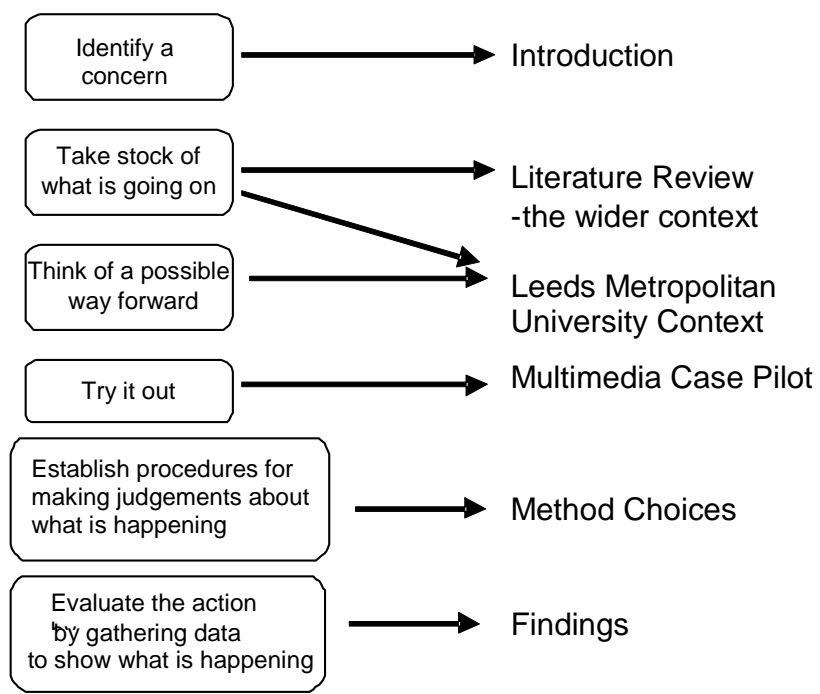


Figure 3: Multimedia Environmental Map

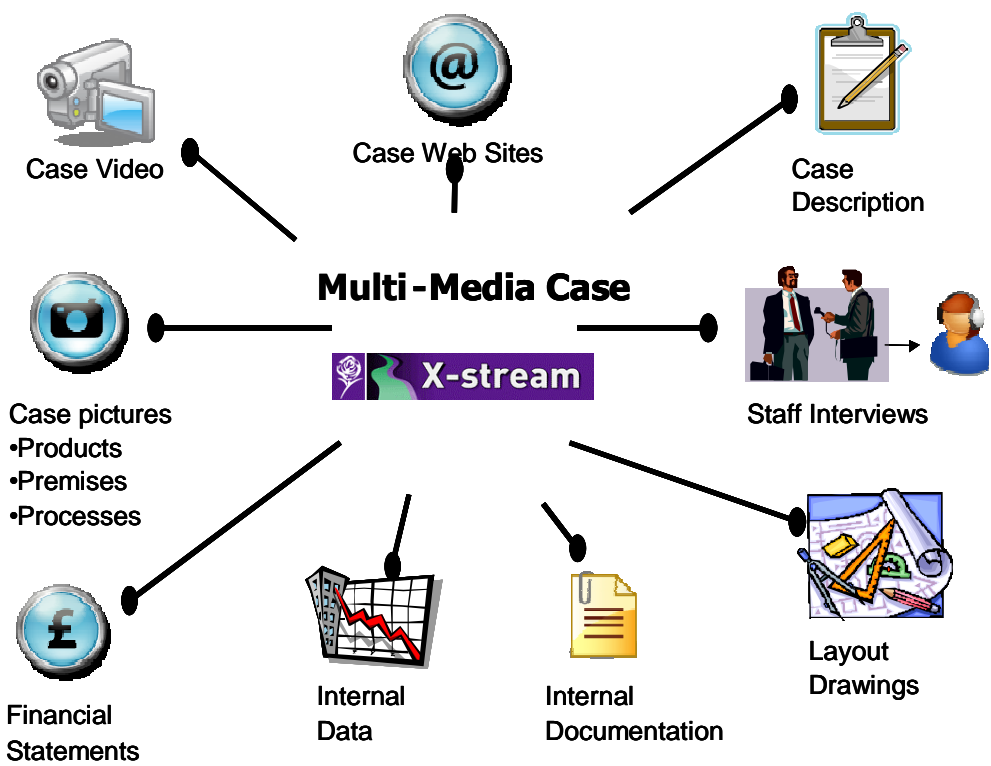

Table 1: Case data collected and compiled

\begin{tabular}{|l|l||}
\hline Video footage of operation & Financial statements \\
\hline Product photos & Photos of equipment, areas and warehouses \\
\hline Demand data (Excel sheets) & Works Order documentation (scanned images) \\
\hline Layout diagrams & Inventory data \\
\hline Video footage of key processes & Text Introduction \\
\hline Organization diagrams & Company website \\
\hline Audio interviews with staff (podcasted) & Meeting minutes (fabricated) \\
\hline
\end{tabular}


Table 2: Most Popular Hits from the VLE Case Site

\begin{tabular}{|l|c|c|c|}
\hline Assessment files & \multicolumn{1}{|c|}{ VLE Hits } & Hits per student & Ratio \\
\hline Video Streaming of case & 1479 & 7.9 & $\mathbf{9 \%}$ \\
\hline Introduction & 1138 & 6.1 & $\mathbf{7 \%}$ \\
\hline Assessment case overview & 1041 & 5.5 & $\mathbf{7 \%}$ \\
\hline Ground Floor Layout & 673 & 3.6 & $\mathbf{4 \%}$ \\
\hline 2006 Demand profile & 422 & 2.2 & $\mathbf{3 \%}$ \\
\hline Case Website: & 399 & 2.1 & $\mathbf{3 \%}$ \\
\hline Other & 10707 & 57 & $\mathbf{6 8 \%}$ \\
\hline Total & $\mathbf{1 5 8 5 9}$ & & \\
\hline
\end{tabular}

Figure 4: Hits from the "Other" Section

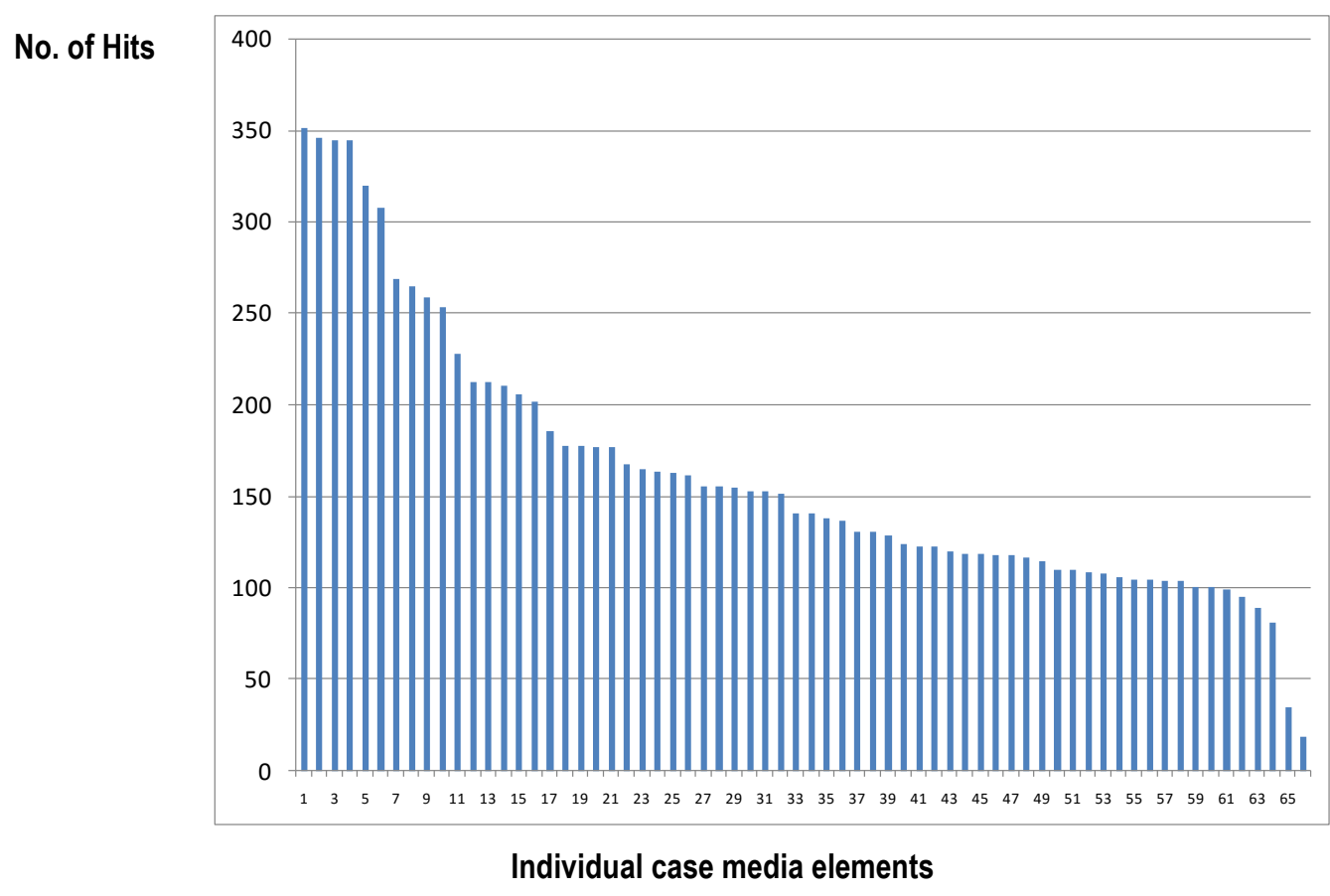


Figure 5a: Case Realism Quantitative Survey Data

The multi-media case is more realistic than a standard paper case

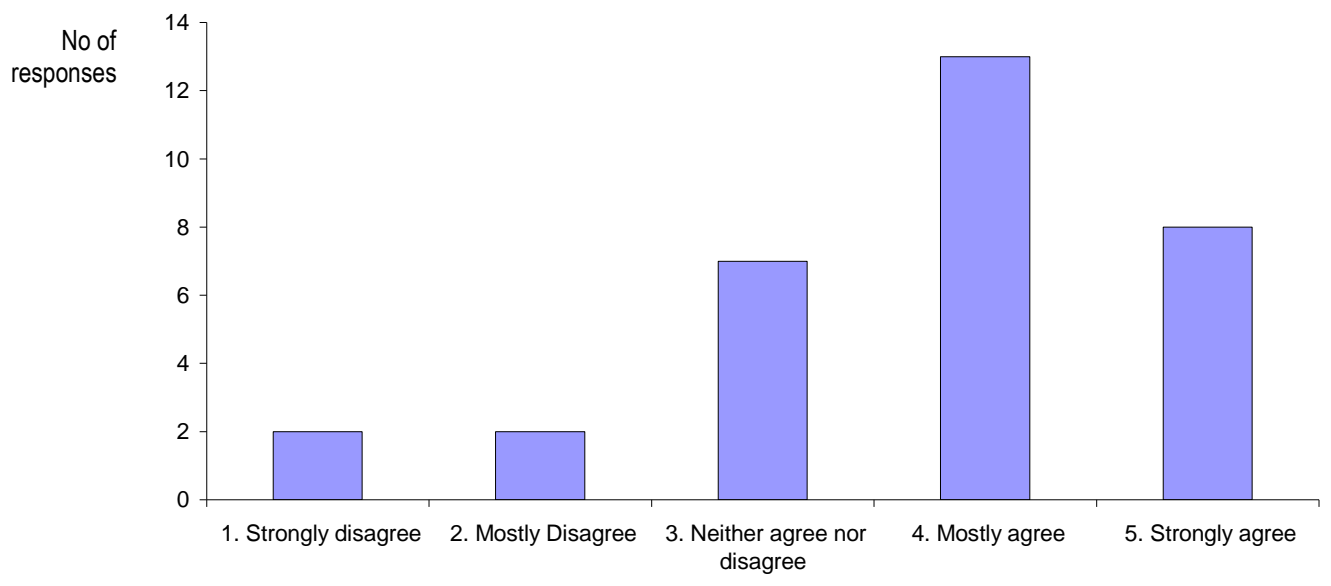

Figure 5b: Case Complexity Quantitative Survey Data

Did the multi-media case appear more complex than a paper case?

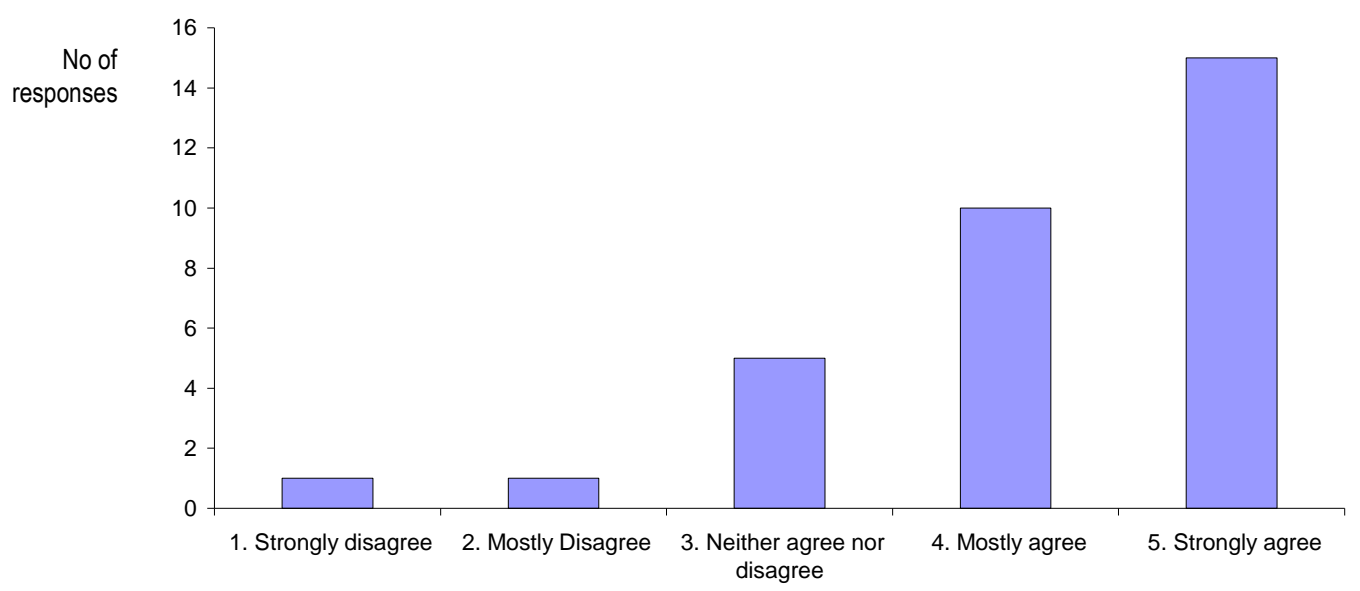


Figure 5c: Suitability Survey Data

On balance is a multi-media case suitable for student studies ?

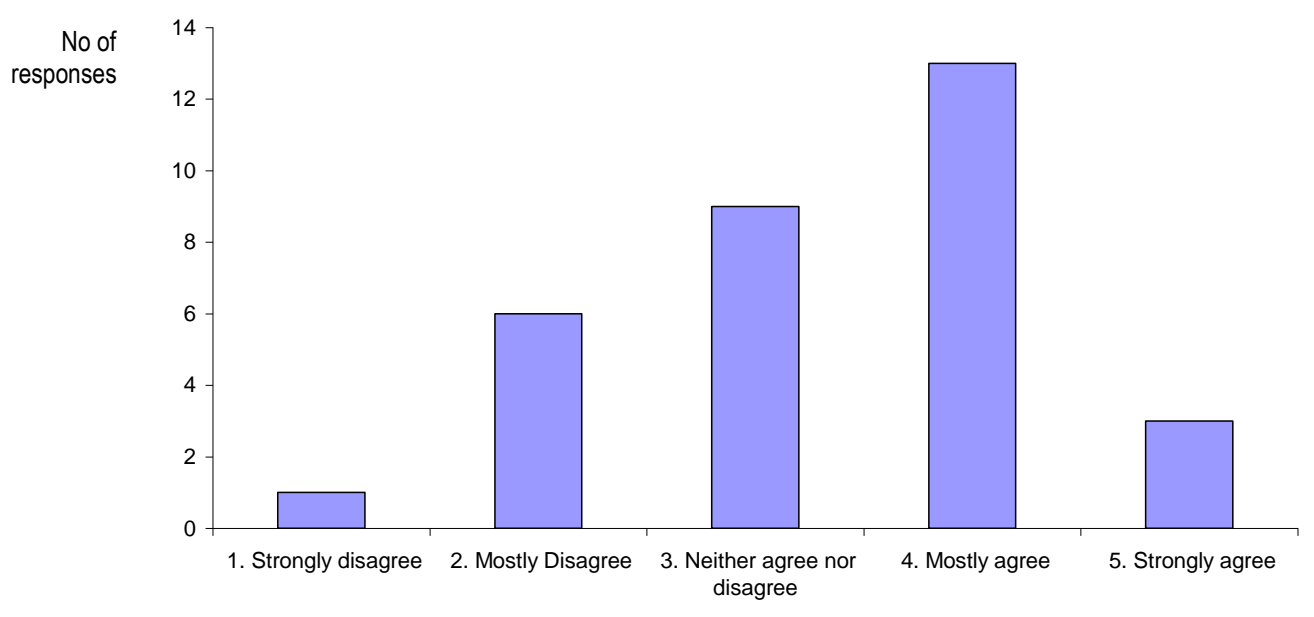


Table 3: Qualitative Comment Mapping

\begin{tabular}{|c|c|}
\hline Issue & Student Comments \\
\hline $\begin{array}{l}\text { Did the students } \\
\text { engage in the } \\
\text { case and find it } \\
\text { stimulating? }\end{array}$ & $\begin{array}{l}\text { "I really like the assessment on a real business and the different } \\
\text { media you get to learn from" } \\
\text { "Interesting, yes. Obviously not something I would normally look } \\
\text { at, but because it was different and you wouldn't normally look at } \\
\text { it, it made it more interesting" } \\
\text { "the assessment task was interesting" } \\
\text { "I wouldn't say it was particularly interesting, but it was definitely } \\
\text { more interesting than it would have been just having a case } \\
\text { written, because you could see what was going on" } \\
\text { "it's quite good because you get to see all the accounts and } \\
\text { everything, and all in the in-depth detail of how they actually } \\
\text { manufacture" }\end{array}$ \\
\hline $\begin{array}{l}\text { Did the case } \\
\text { appear complex to } \\
\text { the students? }\end{array}$ & $\begin{array}{l}\text { "The multimedia assessment was far more imposing and complex } \\
\text { than a simple paper case study" } \\
\text { "It was a bit overwhelming at first, but I found that once you } \\
\text { looked at the assessment material and listened to the different } \\
\text { [elements] it all fell into place." } \\
\text { "It was confusing at times... and it wasn't easy to understand } \\
\text { either" } \\
\text { "Quite a lot of detail, and things to take in at once." } \\
\text { "So although it's all separate it's still complex" } \\
\text { "I think it's harder than a paper case because it is separate bits, } \\
\text { but some of them do link together to answer the question" }\end{array}$ \\
\hline $\begin{array}{l}\text { Did the case help } \\
\text { develop sense- } \\
\text { making skills and } \\
\text { demonstrate ability } \\
\text { to handle } \\
\text { ambiguous and } \\
\text { complex situations }\end{array}$ & $\begin{array}{l}\text { "You have to look at lots of different aspects of things and you've } \\
\text { got to link them all together, it's not just there in front of you when } \\
\text { you set out" } \\
\text { "You can look at it separately, still you've got to fit it together" } \\
\text { "[The case] scared me, but once I actually went through it, it } \\
\text { seemed that it was set out in a certain way which I could }\end{array}$ \\
\hline
\end{tabular}




\begin{tabular}{|c|c|}
\hline & $\begin{array}{l}\text { understand." } \\
\text { "It was a bit overwhelming at first, but I found that once you } \\
\text { looked at the assessment material and listened to the different } \\
\text { [elements] it all fell into place" } \\
\text { "I think that's because it's separate documents, some of them do } \\
\text { link together to answer the question" }\end{array}$ \\
\hline $\begin{array}{l}\text { Did the approach } \\
\text { help develop } \\
\text { student } \\
\text { information } \\
\text { gathering/sifting } \\
\text { skills? }\end{array}$ & $\begin{array}{l}\text { "It was quite hard to get the good stuff out of it to use, because } \\
\text { there was quite a lot of stuff that wasn't relevant" } \\
\text { "It tested our skills" } \\
\text { "I like the way that you can put it together because it's giving you } \\
\text { the skills for outside in the work environment" } \\
\text { "You have to find the information yourself" } \\
\text { "You'd see the whole and you'd get to look at exactly what they're } \\
\text { doing, so I thought it was quite useful for management purposes" }\end{array}$ \\
\hline $\begin{array}{l}\text { Did the case } \\
\text { reflect reality more } \\
\text { closely? }\end{array}$ & $\begin{array}{l}\text { "You see real people and see what is going on, [other cases] are } \\
\text { just a story - put in these facts and figures and working it out from } \\
\text { there". } \\
\text { "In the real world you have to look at lots of different aspects of } \\
\text { things and you've got to link them all together, it's not just there in } \\
\text { front of you when you set out" }\end{array}$ \\
\hline $\begin{array}{l}\text { Did the case help } \\
\text { students engage } \\
\text { in less surface } \\
\text { learning, and more } \\
\text { deep learning? }\end{array}$ & $\begin{array}{l}\text { "I think it's harder than a paper case because it is separate bits, } \\
\text { but some of them do link together to answer the question" } \\
\text { "not totally being comfortable in the understanding of the } \\
\text { assignment" } \\
\text { "It wasn't given to us on a plate" } \\
\text { "You could get a better insight into it, I think." }\end{array}$ \\
\hline
\end{tabular}


Table 4: Mapping Learning Outcomes to Conceptions of Learning

\begin{tabular}{|c|c|c|}
\hline Outcomes of leaning & Conceptions of learning & Level \\
\hline $\begin{array}{l}\text { (1) Mentioning: Incoherent bits of } \\
\text { information without any obvious } \\
\text { structure }\end{array}$ & Acquiring Information routinely & Surface \\
\hline $\begin{array}{l}\text { (2) Describing: Brief descriptions of } \\
\text { topics derived mainly from material } \\
\text { provided }\end{array}$ & $\begin{array}{l}\text { Building up knowledge } \\
\text { Routinely }\end{array}$ & To \\
\hline $\begin{array}{l}\text { (3) Relating: Outline, personal } \\
\text { explanations lacking detail or } \\
\text { supporting argument }\end{array}$ & $\begin{array}{l}\text { Applying knowledge } \\
\text { and skill }\end{array}$ & \multirow{3}{*}{ Deep } \\
\hline $\begin{array}{l}\text { (4) Explaining: Relevant evidence } \\
\text { used to develop structured, } \\
\text { independent arguments }\end{array}$ & $\begin{array}{l}\text { Making sense of ideas and } \\
\text { the real world }\end{array}$ & \\
\hline $\begin{array}{l}\text { (5) Conceiving: Individual } \\
\text { conceptions of topics developed } \\
\text { through reflection }\end{array}$ & Developing as a person & \\
\hline
\end{tabular}


Table 5: Mapping Learning Outcomes to Student Comments

\begin{tabular}{|c|c|c|}
\hline $\begin{array}{l}\text { Outcomes of } \\
\text { leaning }\end{array}$ & $\begin{array}{l}\text { Conceptions } \\
\text { of learning }\end{array}$ & Student comments \\
\hline $\begin{array}{l}\text { (4) Explaining: } \\
\text { Relevant } \\
\text { evidence used } \\
\text { to develop } \\
\text { structured, } \\
\text { independent } \\
\text { arguments }\end{array}$ & $\begin{array}{l}\text { Making } \\
\text { sense of } \\
\text { ideas and } \\
\text { the real world }\end{array}$ & $\begin{array}{l}\text { "You have to look at lots of different aspects } \\
\text { of things and you've got to link them all } \\
\text { together, it's not just there in front of you } \\
\text { when you set out" } \\
\text { "You can look at it separately, still you've got } \\
\text { to fit it together" } \\
\text { "In the real world you have to look at lots of } \\
\text { different aspects of things and you've got to } \\
\text { link them all together, it's not just there in } \\
\text { front of you when you set out" }\end{array}$ \\
\hline $\begin{array}{l}\text { (5) Conceiving: } \\
\text { Individual } \\
\text { conceptions of } \\
\text { topics } \\
\text { developed } \\
\text { through } \\
\text { reflection }\end{array}$ & $\begin{array}{l}\text { Developing } \\
\text { as a person }\end{array}$ & $\begin{array}{l}\text { "It was a bit overwhelming at first, but I found } \\
\text { that once you looked at the assessment } \\
\text { material and listened to the different } \\
\text { [elements] it all fell into place." } \\
\text { "[The case] scared me, but once I actually } \\
\text { went through it, it seemed that it was set out } \\
\text { in a certain way which I could understand." }\end{array}$ \\
\hline
\end{tabular}

